\title{
Dampak ekspor ke tiga negara di kawasan Selat Malaka terhadap penyerapan tenaga kerja Indonesia di sektor pertanian
}

\author{
Emilia; Rahma Nurjanah; Siti Aminah
}

\author{
Prodi Ekonomi Pembangunan Fakultas Ekonomi dan Bisnis Univ. Jambi \\ *E-mail korespondensi: rahma_nurjanah@unja.ac.id
}

\begin{abstract}
This study aims to analyze the development of Indonesia's exports to the three countries in the Malacca Strait of Malaysia, Singapore and Thailand from 1990-2014 and analyzed the effect of exports to these three countries on the absorption of Indonesian labor in the agricultural sector. The result of the research show during the period from 1990- 2014 the value of Indonesia's exports to Malaysia fluctuated or fluctuated with an average value of 3,906.52 million US Dollars and with an average growth of $17.49 \%$,. The value of Indonesian exports to Thailand fluctuated or fluctuated with an average value of 2,255.28 million US dollars with an average growth of $17.11 \%$. During the period of growth the highest occurred in 1998 which amounted to $13.29 \%$ and the lowest growth occurred in 1997 that is -7.76\%. First, second and third model regression results show that Indonesia's export value to Malaysia, Singapore and Thailand has no significant effect on the absorption of labor in agriculture sector.
\end{abstract}

Keywords: Export and labor of agriculture sector

\begin{abstract}
Abstrak
Penelitian ini bertujuan untuk menganalisis perkembangan ekspor Indonesia ke tiga negara di Selat Malaka Malaysia, Singapura dan Thailand dari tahun 1990-2014 dan menganalisis efek dari ekspor ketiga Negara ini tantang peyerapan tenaga kerja di sektor pertanian. Hasil dari penelitian ini menunjukan bahwa selama periode 1990-2014 nilai ekspor Indonesia ke Malaysia berfluktuasi dengan nilai rata-rata 3.906,52 juta Dolar AS dan pertumbuhan nilai rata-rata mencapai $17.49 \%$, Nilai exspor indonesia ke Thailand berfluktuasi dengan nilai rata-rata sebesar 2,255.28 juta Dolar AS dan nilai pertumbuhan nilai rata-rata mencapai $17.11 \%$. selama periode pembangunan. pertumbuhan yang terttinggi terjadi di tahun 1998 yaitu berjumlah $13.29 \%$ dan pertumbuhan terendah yang akut=rat terjadi di tahun 1997 yaitu $-7.76 \%$. hasil dari model regresi pertaa, kedua dan ketiga menunjukan bahwa nilai export Indonesia terhadap Malaysia, Singapore dan Thailand tidak terdapat dampak yang signifikan terhadap absorption pada tenaga kerja di sektor pertanian.
\end{abstract}

Kata kunci: Ekspor dan Tenaga Kerja Sektor Pertanian

\section{PENDAHULUAN}

Hampir setiap Negara di dunia ini yang tidak dapat hidup sendiri karena masingmasing Negara memiliki kekurangan dan kelebihan masing-masing baik dari sisi sumber daya alam maupun sumber daya manusia, atas dasar hal itulah yang melatar belakangi suatu Negara untuk menjalin kerjasama dengan Negara lain termasuk kerjasama dalam bidang ekonomi dalam bentuk perdagangan internasional atau ekspor dan impor.

Indonesia adalah Negara yang menganut sistem perekonomian terbuka dengan melakukan perdagangan dengan Negara lain melalui ekspor dan impor dimana apabila ekspor lebih besar dari impor akan menyumbangkan pendapatan dalam bentuk devisa 
dengan kata lain perdagangan mengalami surplus, selisih antara ekspor dan impor biasa disebut dengan Ekspor neto (Net export).

Peningkatan ekspor suatu Negara tentu sangat baik untuk meningkatkan keadaan eknomi makro seperti pertumbuhan ekonomi dan penyerapan tenaga kerja, pada dasarnya Negara Indonesia memiliki kekayaan sumber daya alam yang terbentang dari sabang sampai merauke sehingga banyak sekali lahan pertanian yang menghasilkan berbagai macam komoditas unggulan yang dapat di ekspor sehingga peningkatan ekspor dapat meningkatkan penyerapan tenaga kerja di sektor pertanian tersebut. Perkembangan jumlah tenaga kerja disektor pertanian sangat diperngaruhi oleh berbagai hal salah satunya adalah makin meningkatnya kebutuhan tenaga kerja disektor tersebut sehingga dengan demikian semakin meningkatnya ekspor disektor pertanian maka kebutuhan pemrintaan tenaga kerja juga akan semakin meningkat.

Sebagai Negara pengekspor Indonesia setiap tahunnya selalu mengekspor barangbarang ke berbagai Negara tujuan apalagi Indonesia yang berada dalam kawasan asia tenggara merupakan mitra perdagangan bagi Negara-negara di kawasan asia tenggara, apalagi saat ini pemberlakukan era perdagangan bebas Masyarakat Ekonomi Asean (MEA) merupakan peluang sekaligus tantangan bagi kinerja ekspor indonesia karena sejak beberapa tahun yang lalu pada tahun 1990 an Negara-negara di asia tenggara yang berada di sekitar selat Malaka seperti Malaysia,singapura dan Thailand merupakan daftar Negara tujuan ekspor, berdasarkan data Asia Development Bank (ADB) pada tahun 1990 nilai ekspor Indonesia ke Malaysia sebesar 253 Juta US Dollar dan pada tahun 2014 mencapai 9.759 Juta US Dollar,sementara nilai ekspor Indonesia ke Thailand pada tahun 1990 sebesar 189 Juta US Dollar dan pada tahun 2014 mencapai 5.830 Juta US Dollar dan Untuk ke singapura nilai ekspor pada tahun 1990 sebesar 1.902 Juta US Dollar dan pada tahun 2014 mencapai 16.052 Juta US Dollar.

Setelah melihat uraian pada bagian latar belakang kita dapat mengidentifikasi masalah yang akan diteliti pada penelitian ini bagaimana perkembangan penyerapan tenaga kerja Indonesia di sektor pertanian dan nilai ekspor ke Malaysia,Thailand dan Singapura periode 1990 sampai 2014, dan bagaimana pengaruh nilai ekspor ke Malaysia,Singapura dan Thailand terhadap penyerapan tenaga kerja di sektor pertanian

\section{METODE}

\section{Bagan alir penelitian}

Bagan alir penelitian ini menggambarkan proses pelaksanaan selama penelitian dilakukan. Karena penelitian ini hanya dilakukan selama satu tahun atau hanya tahun pertama maka rencana penyelesaian penelitian ini dilakukan dalam waktu satu tahun

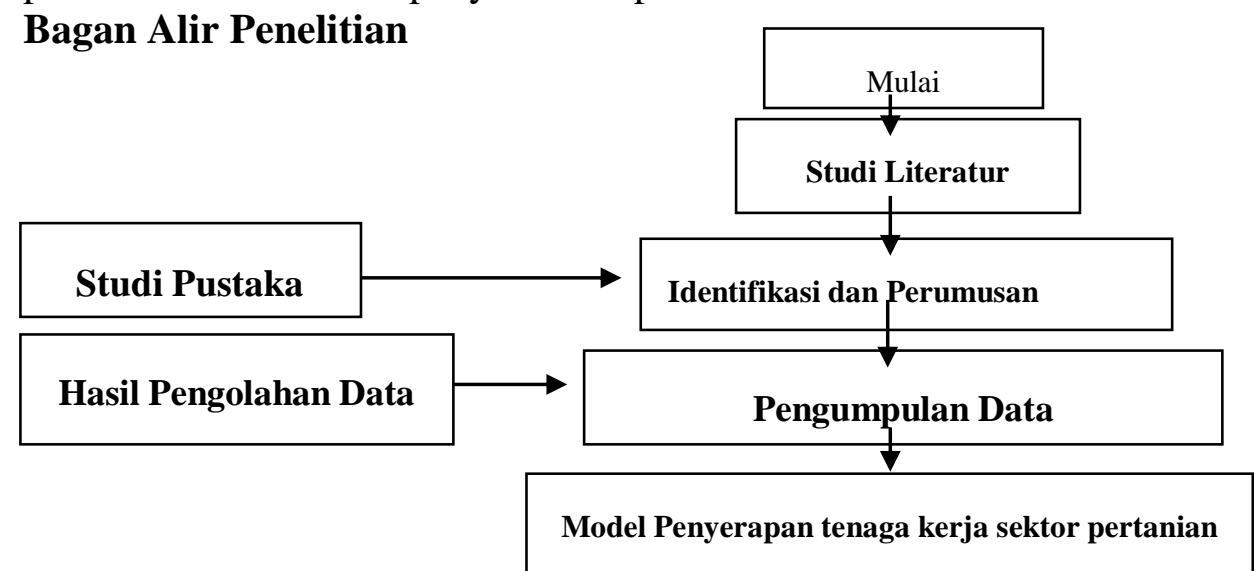

Gambar 1. Bagan alir penelitian 


\section{Diagram Fishbone}

Gasversz (1997) mengungkapkan bahwa "Diagram sebab akibat ini merupakan pendekatan terstruktur yang memungkinkan dilakukan suatu analisis lebih terperinci dalam menemukan penyebab-penyebab suatu masalah, ketidaksesuaian, dan kesenjangan yang ada. Terkait dengan permasalahan dan observasi awal dapat diperlihatkan diagram fishbone sebagai berikut :

\section{Gambar 2 Fishbone Diagram}

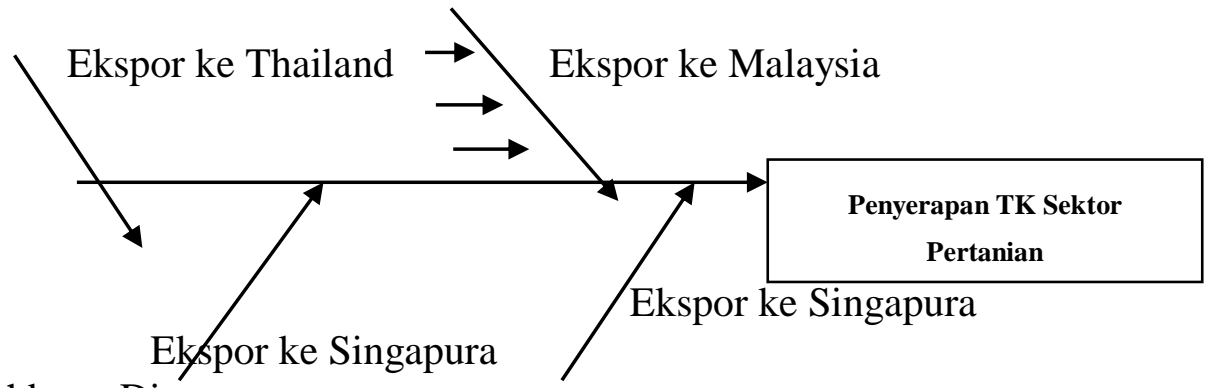

\section{Metode analisis}

Analisis Deskriptif

Merupakan analisis yang dilakukan secara deskriptif untuk memberikan gambaran mengenai perkembangan Variabel-variabel Penelitian, digunakan rumus yakni:

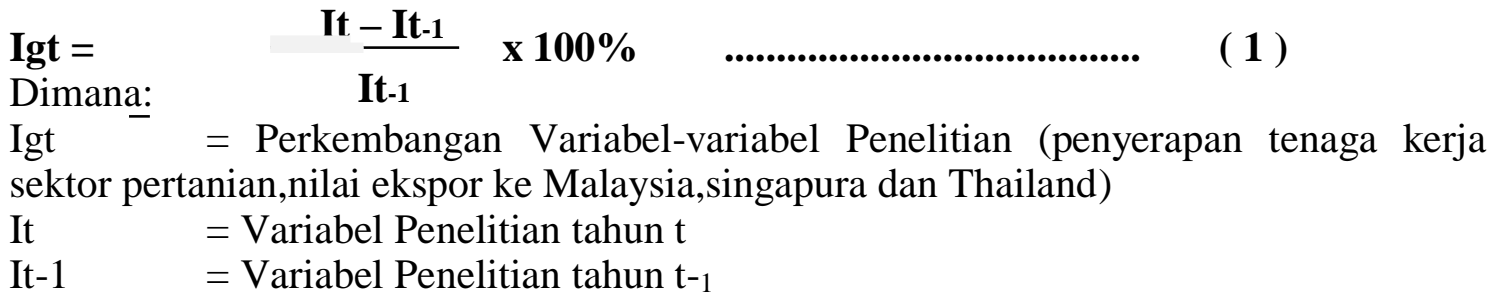

\section{Analisis kuantitatif}

Metode analisis data yang digunakan dalam penelitian ini adalah analisis regresi sederhana dengan metode kuadrat terkecil biasa (Ordinary least square) karena analisis tersebut dapat digunakan sebagai model prediksi terhadap suatu variabel dependen dari satu variabel independen.

yaitu :

$\mathrm{Ep}=\beta_{0}+\beta_{1} \mathrm{Xm}_{\mathrm{t}}+\varepsilon$
$\mathrm{Ep}=\beta_{0}+\beta_{1} \mathrm{Xs}_{\mathrm{t}}+\varepsilon$
$\mathrm{Ep}=\beta_{0}+\beta_{1} \mathrm{Xth}_{\mathrm{t}}+\varepsilon$

$\mathrm{Ep}=\beta_{0}+\beta_{1}$
Dimana :

Ep : Penyerapan tenaga kerja sektor pertanian

Xm : Nilai Ekspor ke Malaysia

Xs : Nilai Ekspor ke Singapura

Xth : Nilai Ekspor ke Thailand

t : : Tahun 1990 sampai 2014

$\beta_{0} \quad$ : Konstanta

$\beta_{1} \quad$ : Koefisien Regresi Variabel Independen (Nilai Ekspor)

$\varepsilon \quad$ : Error term 


\section{HASIL DAN PEMBAHASAN}

Perkembangan ekspor Indonesia ke Malaysia

Untuk mengetahui perkembangan ekspor Indonesia ke Malaysia selama periode tahun $=1990$ sampai 2014 dapat dilihat pada tabel berikut ini

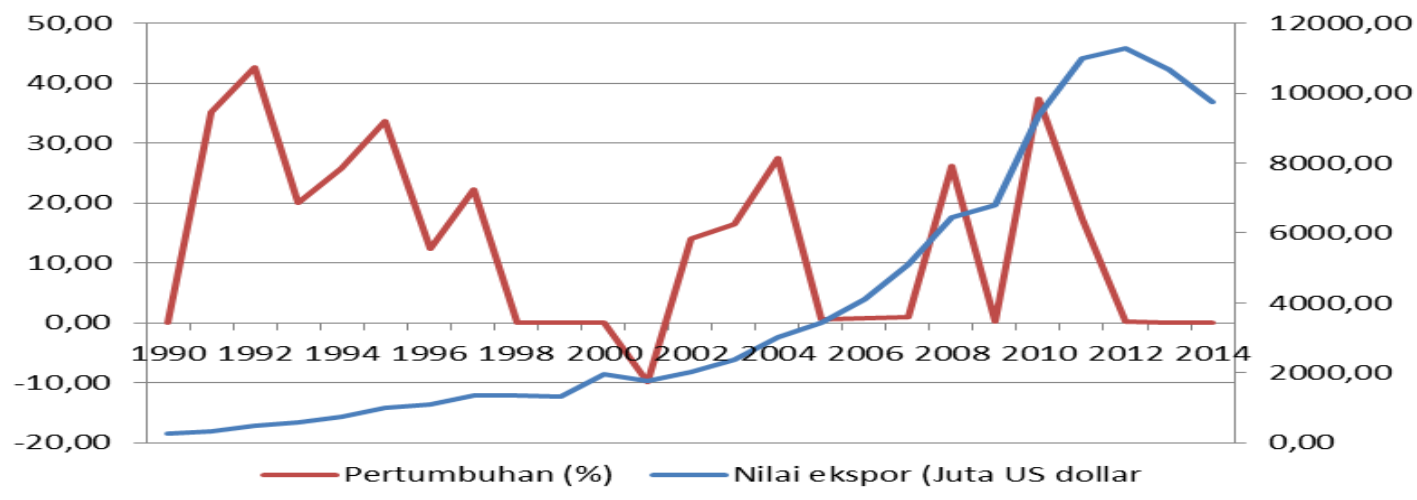

Sumber : ADB (Asian Development Bank)

Gambar 3 Perkembangan nilai ekspor Indonesia ke Malaysia

Dari Gambar. 3 terlihat bahwa selama periode dari tahun 1990 sampai tahun 2014 nilai ekspor Indonesia ke Malaysia berfluktuasi atau naik turun dengan nilai rata-rata sebesar 3.906,52 Juta US Dollar dan dengan rata-rata pertumbuhan sebesar 17,49\%, selama periode tersebut pertumbuhan nilai ekspor tertinggi terjadi pada tahun 2000 yakni $47,6 \%$ dan pertumbuhan terendah terjadi pada tahun 2001 yakni $-9,78 \%$.

\section{Perkembangan ekspor Indonesia ke Thailand}

Untuk mengetahui data perkembangan nilai ekspor Indonesia ke Thailand selama periode tahun 1990 sampai 2014 dapat dilihat pada tabel berikut ini :

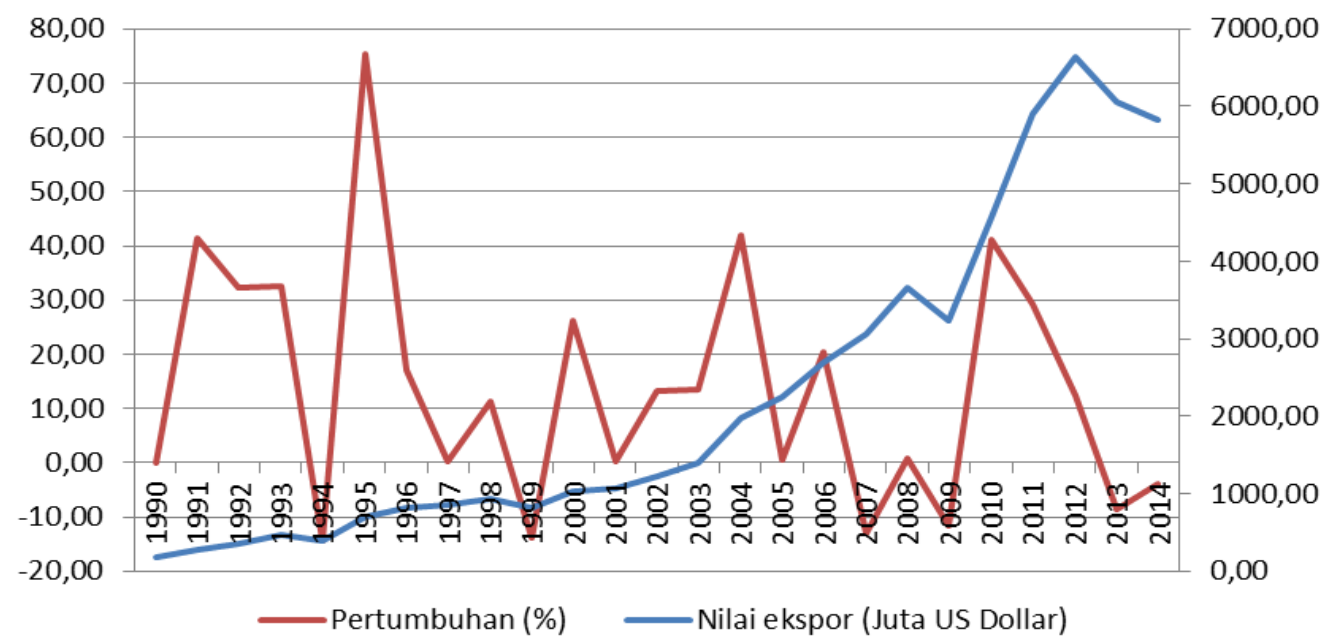

Sumber : ADB (Asian Development Bank)

Gambar 4 Perkembangan nilai ekspor Indonesia ke Thailand

Berdasarkan dari informasi Gambar. 4 terlihat bahwa selama periode tahun 1990 sampai 2014 nilai ekspor Indonesia ke Thailand mengalami fluktuasi atau naik turun dengan nilai rata-rata sebesar 2.255,28 Juta US dollar dengan rata-rata pertumbuhan sebesar $17,11 \%$, selama periode tersebut pertumbuhan tertinggi terjadi pada tahun 2004 yakni $41,85 \%$ dan pertumbuhan terendah terjadi pada tahun 1994 sebesar $-14,31 \%$. 


\section{Perkembangan nilai ekspor Indonesia ke Singapura}

Untuk mengetahui data perkembangan nilai ekspor Indonesia ke singapura selama periode tahun 1990 sampai 2014 dapat dilihat pada tabel berikut ini :

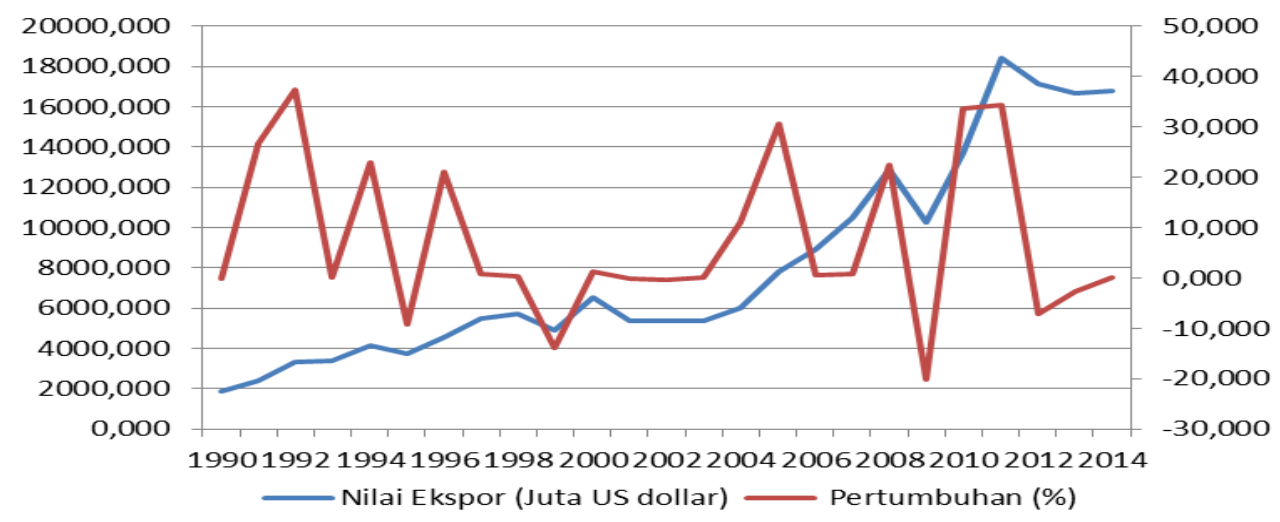

Sumber : Asian Development Bank

Gambar 5 Perkembangan nilai ekspor Indonesia ke Singapura

Berdasarkan informasi dari gambar. 5 terlihat selama periode penelitian tahun 1990 sampai 2014 nilai ekspor Indonesia ke singapura mengalami fluktuasi atau naik turun dengan nilai rata-rata sebesar 8.058,48 Juta US dollar dengan tingkat rata-rata pertumbuhan sebesar $10,9 \%$, selama periode tersebut pertumbuhan tertinggi terjadi pada tahun 1992 yakni 37,51\% dan pertumbuhan terendah terjadi pada tahun 2001 yakni $18,25 \%$.

\section{Perkembangan Tenaga kerja Indonesia di sektor pertanian}

Untuk mengetahui perkembangan tenaga kerja Indonesia yang bekerja di sektor pertanian selama periode tahun 1993 sampai 2014 dapat dapat dilihat pada tabel berikut ini :

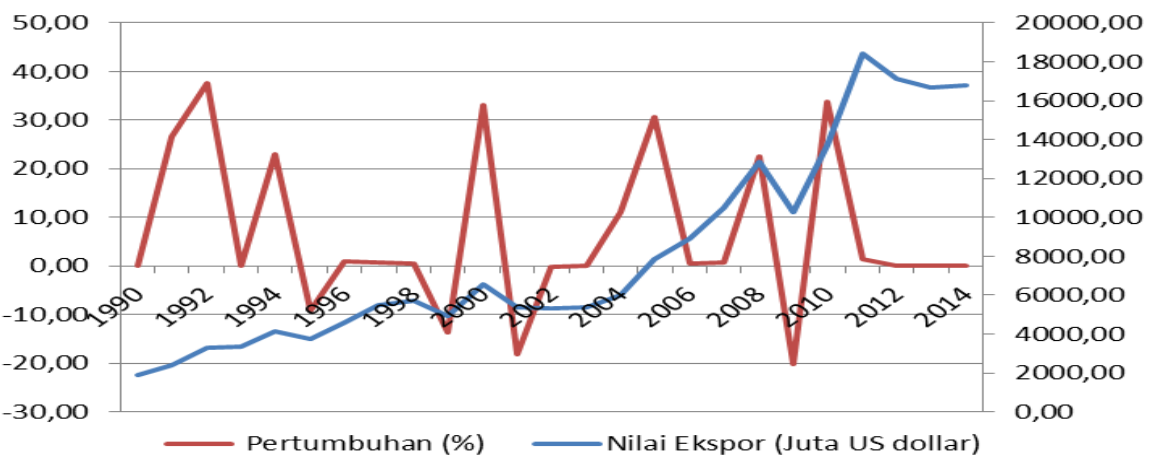

Sumber : ADB (Asian Development Bank)

Gambar 6. Perkembangan tenaga kerja Indonesia di sektor pertanian

Dari gambar.6 terlihat bahwa selama periode penelitian dari tahun 1990 sampai 2014 data tenaga kerja Indonesia yang bekerja di sektor pertanian mengalami fluktuasi atau naik turun dengan nilai rata-rata sebesar 39.896,12 dalam ribu orang dengan ratarata pertumbuhan sebesar $-0,23 \%$, selama periode tersebut pertumbuhan tertinggi terjadi pada tahun 1998 yakni sebesar 13,29\% dan pertumbuhan terendah terjadi pada tahun 1997 yakni $-7,76 \%$. 
Hasil regresi

Untuk mengetahui pengaruh ekspor ke Malaysia terhadap tenaga kerja sektor pertanian pada model pertama dapat dilihat pada tabel berikut ini :

Tabel 1. Hasil Regresi tenaga kerja sektor pertanian dan ekspor ke Malaysia

\begin{tabular}{lrllr}
\hline \multicolumn{1}{c}{ Variable } & Coefficient & Std. Error & t-Statistic & \multicolumn{1}{c}{ Prob. } \\
\hline \multicolumn{1}{c}{ C } & 39769.84 & 599.4825 & 66.34029 & 0.0000 \\
XMAL & 0.032326 & 0.111545 & 0.289798 & 0.7746 \\
\hline R-squared & 0.003638 & Mean dependent var & 39896.12 \\
Adjusted R-squared & -0.039682 & S.D. dependent var & 2018.844 \\
S.E. of regression & 2058.510 & Akaike info criterion & 18.17397 \\
Sum squared resid & 97461693 & Schwarz criterion & 18.27148 \\
Log likelihood & -225.1746 & F-statistic & 0.083983 \\
Durbin-Watson stat & 0.848939 & Prob(F-statistic) & 0.774567 \\
\hline
\end{tabular}

Sumber : Data diolah,2017

Dari hasil regresi pada tabel.1 terlihat bahwa secara Uji t Hitung statistik nilai t hitung sebesar 0,28 dengan probabilitas melebihi batas signifikansi alpha 10\% sehingga dapat disimpulkan bahwa nilai ekspor ke Malaysia tidak berpengaruh signifikan terhadap penyerapan tenaga kerja Indonesia di sektor pertanian.

Sementara itu untuk mengetahui pengaruh ekspor ke singapura terhadap tenaga kerja sektor pertanian pada model kedua dapat dilihat pada tabel berikut ini :

Tabel 2. Hasil regresi tenaga kerja sektor pertanian dan ekspor ke singapura

\begin{tabular}{lrllr}
\hline \multicolumn{1}{c}{ Variable } & Coefficient & Std. Error & t-Statistic & \multicolumn{1}{c}{ Prob. } \\
\hline \multicolumn{1}{c}{ C } & 39873.77 & 785.3441 & 50.77236 & 0.0000 \\
XSIN & 0.002773 & 0.082934 & 0.033436 & 0.9736 \\
\hline R-squared & 0.000049 & Mean dependent var & 39896.12 \\
Adjusted R-squared & -0.043428 & S.D. dependent var & 2018.844 \\
S.E. of regression & 2062.215 & Akaike info criterion & 18.17757 \\
Sum squared resid & 97812812 & Schwarz criterion & 18.27508 \\
Log likelihood & -225.2196 & F-statistic & 0.001118 \\
Durbin-Watson stat & 0.843627 & Prob(F-statistic) & 0.973615 \\
\hline
\end{tabular}

Sumber: Data diolah,2017

Dari hasil regresi pada table. 2 diperoleh nilai $\mathrm{t}$ hitung sebesar 0,28 dengan probabilitas melebihi batas signifikansi alpha $10 \%$ sehingga dapat disimpulkan bahwa ekspor ke singapura tidak berpengaruh signifikan terhadap penyerapan tenaga kerja di sektor pertanian.Sementara itu untuk mengetahui pengaruh ekspor ke Thailand terhadap penyerapan tenaga kerja Indonesia di sektor pertanian pada model ketiga dapat dilihat pada tabel berikut ini :

Tabel 3. Hasil regresi ekspor tenaga kerja sektor pertanian dan ekspor ke Thailand

\begin{tabular}{lrllr}
\hline \multicolumn{1}{c}{ Variable } & Coefficient & Std. Error & t-Statistic & \multicolumn{1}{c}{ Prob. } \\
\hline \multicolumn{1}{c}{ C } & 39818.88 & 617.2406 & 64.51111 & 0.0000 \\
XTHA & 0.034250 & 0.203714 & 0.168130 & 0.8680 \\
\hline R-squared & 0.001228 & Mean dependent var & 39896.12 \\
Adjusted R-squared & -0.042197 & S.D. dependent var & 2018.844 \\
S.E. of regression & 2060.999 & Akaike info criterion & 18.17639 \\
Sum squared resid & 97697493 & Schwarz criterion & 18.27390 \\
Log likelihood & -225.2048 & F-statistic & 0.028268 \\
Durbin-Watson stat & 0.847247 & Prob(F-statistic) & 0.867951 \\
\hline
\end{tabular}

Sumber: Data diolah,2017 
Berdasarkan dari hasil regresi tabel. 3 diperoleh nilai t hitung statistic sebesar 0,16 dengan signifikansi probabilitas melebihi alpha $10 \%$ sehingga dapat disimpulkan bahwa nilai ekspor ke Thailand tidak berpengaruh signifikan terhadap penyerapan tenaga kerja disektor pertanian.

\section{Implikasi ekonomi}

Berdasarkan hasil regresi dari ke tiga model regresi sederhana diatas di peroleh informasi ternyata tidak ada satupun model yang menghasilkan pengaruh yang signifikan antara ekspor ke tiga Negara tersebut yakni Malaysia, singapura dan Thailand terhadap penyerapan tenaga kerja Indonesia di sektor pertanian dengan demikian hal ini dapat dijelaskan bahwa apapun yang terjadi pada ekspor Indonesia ke tiga Negara tersebut tidak akan berpengaruh terhadap serapan tenaga kerja di sektor pertanian, hal ini mengindikasikan bahwa sektor pertanian tidak mampu menghasilkan komoditas barang ekspor ke tiga Negara tersebut yang mampu meningkatkan serapan tenaga kerja, sektor pertanian di Indonesia ternyata bukanlah sektor yang menjanjikan bagi tenaga kerja Indonesia dan komoditas barang pertanian yang di ekspor tidak mampu menyerap tenaga kerja lebih banyak katrena rata-rata komoditas barang pertanian seperti sawit,karet dan lain lain tidak mampu menyerap tenaga kerja lebih banyak, produktifitas yang rendah dengan pendapatan yang rendah merupakan indikasi kurangnya minat bagi tenaga kerja Indonesia bekerja di sektor pertanian.

Komoditas barang eskpor yang masih mengandalkan barang mentah dari sektor pertanian perlu menjadi perhatian bagi pemerintah agar sektor ini tidak di tinggalkan oleh masyarakat atau tenaga kerja khususnya di pedesaan, perlu inovasi dan diversifikasi sehingga peningkatan ekspor mampu menyerap tenaga kerja khususnya di sektor pertanian.

\section{KESIMPULAN DAN SARAN}

\section{Kesimpulan}

Adapun poin penting yang dapat disimpulkan selama periode dari tahun 1990 sampai tahun 2014 nilai ekspor Indonesia ke Malaysia berfluktuasi atau naik turun dengan nilai rata-rata sebesar 3.906,52 Juta US Dollar dan dengan rata-rata pertumbuhan sebesar $17,49 \%$, selama periode tersebut pertumbuhan nilai ekspor tertinggi terjadi pada tahun 2000 yakni 47,6\% dan pertumbuhan terendah terjadi pada tahun 2001 yakni $-9,78 \%$. nilai ekspor Indonesia ke Thailand mengalami fluktuasi atau naik turun dengan nilai rata-rata sebesar 2.255,28 Juta US dollar dengan rata-rata pertumbuhan sebesar $17,11 \%$, selama periode tersebut pertumbuhan tertinggi terjadi pada tahun 2004 yakni 41,85\% dan pertumbuhan terendah terjadi pada tahun 1994 sebesar $-14,31 \%$. nilai ekspor Indonesia ke singapura mengalami fluktuasi atau naik turun dengan nilai rata-rata sebesar 8.058,48 Juta US dollar dengan tingkat rata-rata pertumbuhan sebesar $10,9 \%$, selama periode tersebut pertumbuhan tertinggi terjadi pada tahun 1992 yakni 37,51\% dan pertumbuhan terendah terjadi pada tahun 2001 yakni 18,25\%. selama periode penelitian dari tahun 1990 sampai 2014 data tenaga kerja Indonesia yang bekerja di sektor pertanian mengalami fluktuasi atau naik turun dengan nilai rata-rata sebesar 39.896,12 dalam ribu orang dengan rata-rata pertumbuhan sebesar $-0,23 \%$, selama periode tersebut pertumbuhan tertinggi terjadi pada tahun 1998 yakni sebesar 13,29\% dan pertumbuhan terendah terjadi pada tahun 1997 yakni $-7,76 \%$. Hasil regresi model pertama, kedua dan ketiga menunjukkan bahwa nilai ekspor Indonesia ke 
Malaysia , singapura dan Thailand tidak berpengaruh signifikan terhadap penyerapan tenaga kerja di sektor pertanian.

\section{Saran}

Pemerintah perlu memberikan perhatian yang serius terhadap sektor pertanian dengan ketersediaan lahan yang luas di pedesaan di harapkan peningkatan produksi pertanian dapat meningkatkan ekspor dan meningkatkan pendapatan tenaga kerja di sektor pertanian sehingga sektor ini diharapakan tetap mampu membantu pemerintah mengurangi angka penagngguran. Perlu adanya diversifikasi dan inovasi yang lebih baik di sektor pertanian serta bagai peneliti lanjutan perlu kajian yang lebih dalam untuk melihat transmisi eskpor dengan tenaga kerja di sektor pertanian.

\section{DAFTAR PUSTAKA}

ADB, (2014). Economic Indicators from : www.adb.org

Agus,Salim.(2005), Analisis Keterkaitan Antara Pengeluaran Pemerintah Pertumbuhan Ekonomi Ketimpangan Distribusi Pendapatan dan Kemiskinan di Indonesia 19762004, Disertasi Program Pascasarjana Unpad (tidak dipublikasikan).

Dornbusch.R.(2001). Macro economic, The Mc Graw Hill Companies.Inc.New york

Dumairy.(1996). Perekonomian Indonesia : PT. Airlangga. Jakarta

Gaspersz,Vincent.(1997). Manajemen Kualitas Penerapan Konsep-Konsep Kualitas Dalam Manajemen Bisnis Total. Jakarta: PT. Gramedia Pustaka Utama

Greene.H.William.(2000). Econometric Analysis, $4^{\text {th }}$ Edition, Prentice-Hall, New Jersey.

Gujarati,Damodar N. (2003). Basic Econometrics.. Fourth edition, International Edition. MC Grow Hill.

Junaidi.;Zulgani (2011). Peranan Sumberdaya Ekonomi dalam Pembangunan Ekonomi Daerah. Jurnal Pembangunan Daerah Edisi III; 27-33.

Lindert, Peter H.(1994). Ekonomi Internasional (Edisi 9), Bumi Aksara, Jakarta.

Mankiw, N. Gregory. (2003). Teori Makro Ekonomi. Alih Bahasa Iman Nurmawan dan Editor Wisnu C Kristiadi.

Mudrajad,Kuncoro.(2003). Metode Riset untuk Bisnis dan Ekonomi : Bagaimana Meneliti dan Menulis Tesis?, Jakarta : Erlangga.

Mustika,Candra.;Amril.(2015).Analisis Pengaruh Ekspor ke Jepang Terhadap Pertumbuhan Ekonomi dan Jumlah Pengangguran di Indonesia Periode 1993 sampai 2013. Jurnal Paradigma Ekonomika, 10(1); 246-260

T.Froyen.(2005).Macro economics, Theories and Policies, Eight edition. Pearson Prentice Hall.

Todaro, Michael P.;Stephen C.Smith.(2003). Economic Development, Eight Edition.The Addison.Wesley.

Van,den,Berg.;Hendrik.(2001). Economic Growth and evelopment, Applied Econometrics and International Development, 2(1);73-78 